\title{
Bodies in Peril: French Sculpture and the Return of Flemishness
}

\author{
TOMAS MacsotaY*
}

Bodies in Peril: French Sculpture and the Return of Flemishness

\begin{abstract}
The presence of Netherlandish sculptors who migrated to France among the pioneer members of the Académie Royale is well documented, but it does not stand as the only point of contact between the two visual traditions. Around 1700 the qualities associated with a Flemish and Dutch image-repertoire offered further points of departure for French sculptors. This visual integration rested on concepts that emerge in contemporary French art theory, as can be illustrated in passages from Roger de Piles and Claude-Henri Watelet, as well as by the sculptor Etienne-Maurice Falconet. Rather than a concept of truth to optical perception, critics spoke of a type of image that shows sudden and disruptive events, as if exposed by a sudden flash, leaving beholders struck and breathless. Part of a transition from the rhetorical energeia-enargeia in direction of a new notion of pictorial magie, the criticism of the Flemish violent image and body becomes manifest, I will argue, through works of sculpture exhibited as early as the Salons of 1699 and 1704.
\end{abstract}

\section{COSSOS EN PERILL: L'ESCULTURA FRANCESA I EL RETORN DE L'ART FLAMENC}

Resum

La presència d'escultors neerlandesos emigrats a França entre els primers membres del'Académie royale està ben documentada, tot i que aquest no és l'únic vincle establert entre ambdues tradicions visuals. Al voltant de l'any 1700 les característiques associades a un repertori d'imatges flamenco-neerlandeses van oferir als escultors francesos un horitzó de major amplitud. Aquesta incorporació visual es recolzava en conceptes sorgits de la teoria de l'art francès del moment, tal i com ho illustren determinats fragments de les obres de Roger de Piles i Claude-Henri Watelet, així com de l'escultor Etienne-Maurice Falconet. En lloc del concepte de representació fidel a la percepció òptica, aquests autors es referien a un tipus d'imatge que mostra esdeveniments imprevistos i pertorbadors, com si estiguessin exposats a una sobtada fulgor, deixant a l'espectador impressionat i sense alè. En plena transició entre un concepte retòric de energeia-enargeia i un pictòric de la magie, la crítica del cos i la imatge violenta flamenca queden en evidència, tal i com s'exposa al següent article, a través de les obres escultòriques exhibides als Salons de 1699 i 1704.

Macsotay, T., "Bodies in Peril: French Sculpture and the Return of Flemishness", Acta/Artis. Estudis d'Art Modern, 4-5, 2016-2017, pp. 27-39

KEYwORDs: French eighteenth-century sculpture, Netherlandish visual culture, Rubens, art theory, rhetoric, images of violence

PARAUlES CLAU: escultura francesa del segle XVIII, cultura visual holandesa, Rubens, teoria de l'art, retòrica, imatges de la violència

* I wish to extend a heartfelt thank you to Frits Scholten, whose valuable suggestions on Dutch "amusing" sculpture at the start of this investigation have aided me. I also want to thank Bas Nederveen for his kind assistance in finding the literature on Xavery and Baurscheit. The research for this article was made possible by a Marie Curie co-fund grant in the Gerda Henkel FP7 programme. 


\section{The Paris Market}

Whenever artists paid a visit to a potential collector-patron in eighteenth-century Paris, they had a good opportunity to inspect the residence's holdings of old masters, there finding in a majority of cases an imposing number of canvases by Netherlandish masters. According to Patrick Michel's Peinture et Plaisir. Les goûts pictoraux des collectioneurs parisiens au XVIIIe siècle, Paris collectors and dealers in the first half of the century absorbed so many paintings by Rubens that a total of 138 of his works came under the hammer: in the thirty years following 1750, another 249 Rubens canvases appeared on the sales inventories. ${ }^{1}$ Paris's holdings of Teniers were similarly numerous: 125 traded at auctions between 1730 and 1750, 608 between 1750 and 1780 . In the early-mid eighteenth century, the best-selling artists among the northerners were Jan van Goyen, Anthonie van Dijk, Rembrandt van Rijn, Frans van Mieris and Gerard de Lairesse. ${ }^{2}$ A host of other names emerge throughout the later decades (there is a veritable Ruysdael bubble after 1760, with items booming from just two to 125), but Rubens, Rembrandt and Teniers maintained their enormous popularity throughout. ${ }^{3}$

Patrick Michel's magnificent overview of Paris collecting clarifies as much on local painting as it raises new questions on sculpture. Michel does not provide numbers that would help us reconstruct, along these lines, the presence of a taste for collecting sculpture originating in the Low Countries. ${ }^{4}$ But understanding, as we now do, how valued these Netherlandish canvases were, we are faced with a no less interesting challenge. Granted that sculptors in Paris did not have to compete with an "imports" market in their own trade, and that they had this important advantage on the economic conditions afflicting, say, a Parisian landscape painter, it remains true that they were still working largely under competitive conditions, and managing a studio or shop that might have lured buyers by means of a commercial "stock" of models. ${ }^{5}$ The landscape painter's economic success would have been subject in more direct ways to the market for highly-prized Van Goyens and Ruysdaels, but sculptors, while safe from the disadvantages of trade, still had to devise ways of engaging a public that might well have been inclined overwhelmingly toward Dutch imagery.

Of course, the early years of the Académie's history were marked by an influx of sculptors from Flemish and Netherlandish origins. Gerard van Opstal was one of the famed founders of the Académie Royale, and the famous Place des Victoires war memorial, showing Louis XIV on horseback on a plinth surrounded by colossal statues of four captive nations, was a work by Martin Desjardins, a sculptor who left his native Breda to train with the Antwerp sculptor Pieter Verbruggen before embarking on a career as academician in Paris. The direct participation of sculptors from the north in the Parisian academic sculptors' practices would, however, decrease dramatically in the following century. From the 1690 on, it becomes almost impossible to find any Netherlandish sculptors in the Académie's registers in Paris. At that point, exchanges with the Netherlands consisted primarily of a theoretical reception and an enthusiasm among collectors for Dutch and Flemish painting.

1. See Michel, P., Peinture et Plaisir. Les gouts pictoraux des collectioneurs parisiens au XVIII siècle. Rennes: Presses Universitaires de Rennes, 2010. The numbers stem from Michel's quantified analysis on p. 186.

2. Ibidem, p. 186 .

3. The category of "Flemish" painting in sales inventories is slippery, since most collectors understood all Netherlandish, German and Flemish masters as belonging to the École Flamande. See MiEgroet, H.J. van, "Recycling Netherlandish Paintings in Eighteenth-century France", in RAUX, S. (ed.), Collectionner dans les Flandres et la France du Nord au XVIIIe siècle. Lille: University of Lille, 2003, pp. 251-287 (p. 266).

4. On Parisian collecting of sculpture see ScHERF, G., "Collections et collectionneurs de sculptures: un nouveau champ d'étude", in Gaethgens, T. (ed.), L'Art et les normes sociales. Paris: Éditions de la Maison des sciences de l'homme, 2001, pp. 147-162.

5. Schnapper, A., "Collections d'artistes en France au XviIe Siècle: Questions de Méthode”, in BrigANTI, G., Geografia del Collezionismo. Italia e Francia tra il XVI e il XVIII Secolo. Rome: Ecole française de Rome, 2001, pp. 345-356. 
Turning to the early Salons, we see French sculpture moving into iconographical, thematic and stylistic territory that had been developed by Netherlandish artists or for which only Netherlandish precedents existed. From among the sculptures shown in the Salon of 1704, one might single out Jean-Baptiste Poultier's Guitar Player. Born in Huppy, in the northern district of Picardie, Poultier belonged to a well-employed generation of sculptors, and was involved in a plethora of commissions and genres. He was successful at obtaining court employment, producing garden sculpture at Marly, Versailles and Fontainebleau. He obtained his admission to the Paris Académie in 1684 by offering a set of wooden statues of the Virgin and Saint John at the foot of the Cross, figures he prepared originally for the Parish church of Saint-Nicolas-du-Chardonnet in the Quartier de la Place Maubert (later destroyed). ${ }^{6}$ After the economically barren years of Louis XIV's wars, he diversified his stock, and his envoy for the Salon of 1704 consists of an array of potentially erotic works (groups of The Temptation of Adam and Eve; Apollo and Daphne; a Venus; a group of Susanna and The Elders) which show ambition in the private collectors market. It seems likely, although we are only left with the title of the piece, that Guitar Player took up a popular specialism from Antwerp: the terracotta figure of vagrants playing hurdy-gurdies (draailierspelers), as developed by such masters as the Antwerp-born Pieter Xavery and the Amsterdam-based Jan Pieter Baurscheit. ${ }^{7}$ Guitar-playing had been on the rise in painting as well: one of the Netherlandish émigrés or sons of émigrés exhibiting that year was Jacques Vanscuppen, or Vanscippen, who joined the Académie in great haste in 1704, just in time to turn in a cohort of canvases at that year's Salon, identified in the Livret as "Joueuse de guitare" (again, Guitar Player), "Femme lisant une lettre" and "Grouppe de différens oiseaux tuées".

The descriptive or socially expressive studies pioneered in this Salon by Poultier and Vanscuppen are signs of a renewal in audiences and markets. Moreover, the Flemishness of the 1704 Salon was not limited to the Joueurs, as I will argue below. History painters grappled with competition from an imports market by playing with the limits of the historical high genre and collecting elements of pictorial fashion "from below". ${ }^{9}$ But was this possibly also true of sculpture? Was it too placed in a position to engage with Rubens and Rembrandt and introduce a "Netherlandish air" into its portrait busts, its morceaux de réception, its tomb monuments and grands hommes? To pose this question, we might need to consider that the French fashionable earlyto mid-century sculptor was, so to say, "exposed" to market contingencies that encouraged engagement with visual culture from the north. ${ }^{10}$ Such an exchange with the Low Countries coincided with the heyday, within the Académie Royale, of the aesthetic propositions of Roger de Piles. Poultier's Guitar Player has not survived, but its overture to merry life is likely to

6. De Montaiglon, A., et al. (eds.), Procès-verbaux de l'Académie royale de peinture et de sculpture (1648-1793). Paris: Société de l'histoire de l'art français, 1875-1892, vol. 3, p. 143. On Poultier see Delgnières, E., Poultier, sculpteur picard (1653-1719). Paris: E. Plon, Nourrit et Cie., 1897.

7. On Baurscheit see BIJZET, E., "Waer in den Aert en Stand zijn uitgedrukt heel stout. Pieter van Baurscheits Drinkebroers en de boertige kunst in de Nederlanden", Bulletin van het Rijksmuseum, 56, 4, 2008, pp. 425-444; STARING, A., “Aantekeningen op de Hollandsche beeldhouwwerken van J.P. van Baurscheit, vader en zoon", Oudheidkundig Jaarboek, 13, 1946, pp. 45-49; and LammerTs, F., "Four Letters from Adriaen van der Werff to the Antwerp sculptor Jan Peter van Baurscheit", Simiolus, 34, 2, 2009-2010, pp. 119-142. On Xavery see StARInG, A., "De beeldhouwer Pieter Xavery", Oud Holland, 44, 1927, pp. 1-15; and OELINCK, E., "Nieuws over den beeldhouwer Pieter Xavery”, Oud Holland, 59, 1942, pp. $102-109$.

8. On Vanscuppen, see De Montaiglon, A., et al. (eds.), Procès-verbaux..., vol. 1, p. 387 and 399. Next to Vanscuppen, the Livret also mentions the history painter François Marot's "La dame à qui l'on présente du café" in the same genre.

9. See, for instance, Ledbury, M., "Heroes and Villains: History Painting and the Critical Sphere", in MiCHEL, C.; MAGNusson, C. (eds.), Penser l'art dans la seconde moitié du XVIIIe siècle. Paris-Rome: Académie de France à Rome-Somogy éditions d'Art, 2013, pp. 25-39; Christian Michel (MicheL, C., L'Académie royale de peinture et de sculpture (1648-1793). La naissance de l'Ecole Français. Paris: Droz, 2013; and idem, Le Célèbre Watteau. Geneva: Bibliothèque des Lumières, 2008, pp. 165-187) put forward another important criticism of the idea of immutable genre and inflexible history painting which art history has wrongly imputed to academic practices.

10. I shall not recapitulate the rich literature on D'Angiviller's grands hommes. On the patriotic sculpture collector, see the chapter devoted to Abbé Terray in BAILeY, C.B., Patriotic Taste. Collecting Modern Art in Pre-revolutionary Paris. London - New Haven: Yale University Press, 2002, pp. 71-100. 
have left a stamp on the pastoral and elegiac sculpture for which sculptors like Robert le Lorrain, Jacques Saly and Louis-Claude Vassé developed a patent in the early-to-mid-170os. ${ }^{11} \mathrm{An}$ account that examines a broadly termed "dialogue" between French sculpture and Netherlandish art has, as far as I know, only been attempted by Aline Magnien in an engaging book chapter, and it cannot be my ambition to do more than set the terms for a comparison that might need to be further debated and re-examined. Undoubtedly, Rubénisme is the logical place to start. Crucially, as Aline Magnien has shown, the continued debate that carried on in France on the use of colour and qualities of skin in painting could be seen to have informed habits of making and viewing sculpture. The debate referred to here was taking root at the same time in academic circles as well as some testimonies by non-academic masters. Where such discussions dwelled on the treatment of surface and the intricacies of light, shadows and reflections, all of which entered into the effort to show and differentiate skin and other object qualities, Magnien observes that the heart of such reflections even where sculpture is concerned was often to be found in a vivid reception, not of a sculptor from the canon, but of the painter Rubens. ${ }^{12}$ What I would like to consider, and in this I will follow a different course from Magnien, is how the viewing of sculpture might have involved a certain responsiveness to bodies in violent situations, lending these types of sculpture privileged access to what one might consider to be a Flemish pictorial language of visual unity-one that speaks to the technical and analytic merits a sculptor might have pursued by achieving specific effects of light and the representation of skin, yet also represents a less tangential element in the experience of Flemish images. What follows is a narrow exploration of a subset of questions on the likely impact of specific conceptions of the Netherlandish pictorial image as an affective unity. I will argue that the "return to Flemishness" must not be narrowed down to a new taste for the observation of everyday reality. This becomes clear, in part, from the examination of critical languages, for which writings of Etienne-Maurice Falconet will be consulted. But these remarks follow on in equal measure from affinities between the Flemish violent body and French sculpture. The essay closes with a discussion of two further sculptures exhibited in 1704 .

\section{The "Magie" of Netherlandish Canvases}

The writings of Falconet represent a unique opportunity to see some of the choice terms and habitual phraseology an academic sculptor might have used to brandish his familiarity with Netherlandish painting. The opportunities were not rare. Falconet is likely to have started out in his native Paris, and in the years of his residence in Russia, between 1766 and 1778, he deployed a connoisseurial activity that frequently favoured Low Countries masters. ${ }^{13}$ Following Diderot's arrangements for Russian Empress Catherine II's acquisition of the Crozat collection (featuring Netherlandish highlights that included six Van Dycks and a number of works by

11. See for instance the fascinating study of the child portrait or infantile tête d'étude in BLACK, B., Vassé's Bambinelli: the child portraits of an eighteenth-century French sculptor. London: Athlone Press, 1994. On Le Lorrain see BRESC BAUTIER, G.; SCHERF, G. (eds.), Bronzes français de la Renaissance au siècle des Lumières. Paris: Éditions Musée du Louvre, 2008, pp. 416-431.

12. Magnien, A., "Le rubénisme dans la sculpture: la couleur, le coloris et la chair", in Heck, M.-C. (ed.), Le Rubénisme en Europe aux XVIIe et XVIIIe siècle. Turnhout: Brepols, 2006, pp. 113-124.

13. See RÉAU, L., Etienne-Maurice Falconet 1716-1791. Paris: Demotte, 1922, pp. 91-108. 


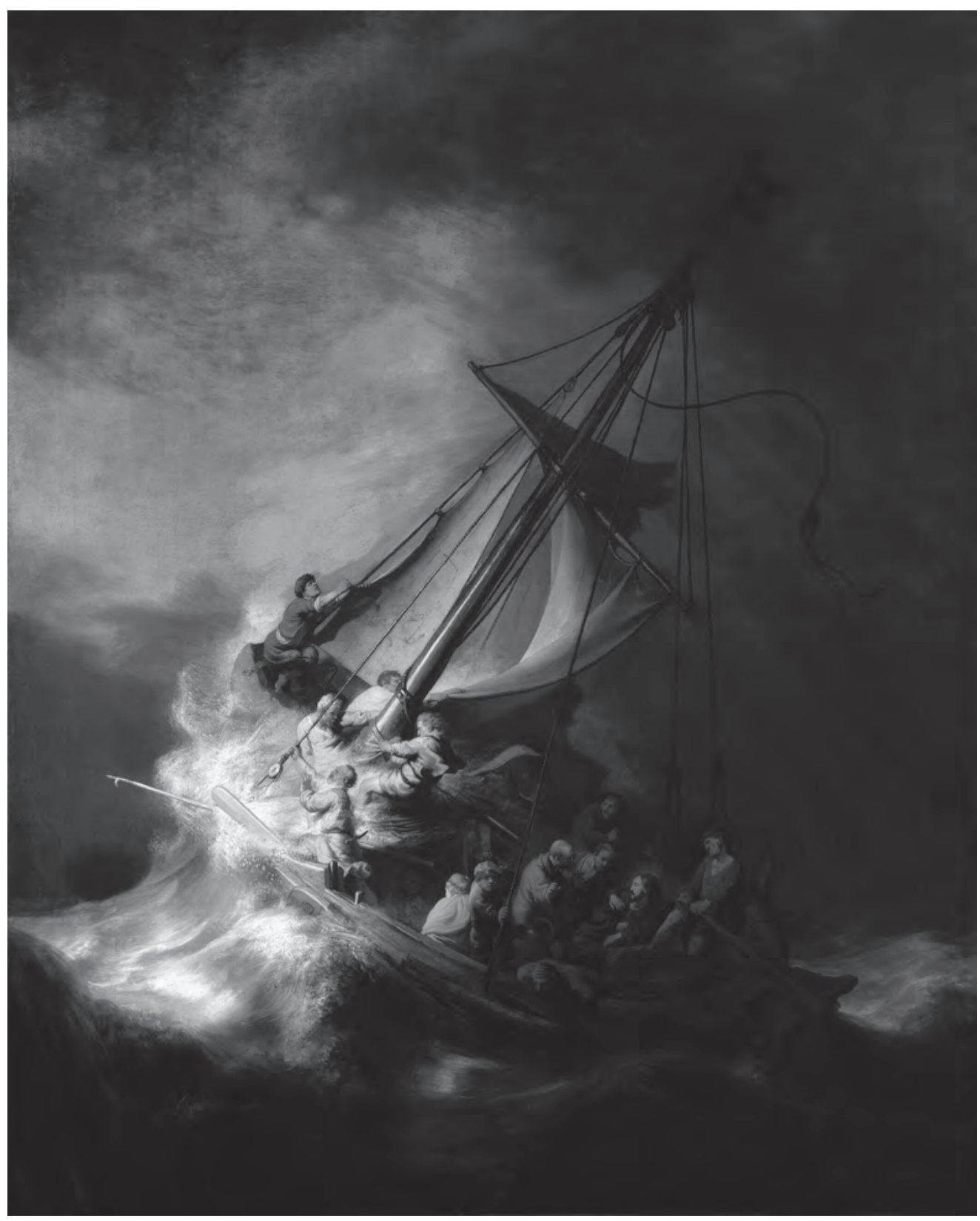

1. Rembrandt van Rijn Storm on the Sea of Galilee, 1633, oil on canvas $160 \times 128 \mathrm{~cm}$ Present whereabouts unknown.

Wouwermans, Rubens and Rembrandt, including the latter's Danaë), ${ }^{14}$ Falconet continued to advise Catherine II on possible Rembrandt purchases (Mordechai before Esther and Ahasver$u s),{ }^{15}$ on Berghem, Dou and van Dijk. ${ }^{16}$ More of this went on in The Hague, Leiden and Amsterdam. It is well known that Falconet's visits to the Low Countries between 1779 and 1780 were of a personal nature, as the sculptor came to convert his writings on the visual arts into an

14. RÉAU, L. (ed.), Correspondance de Falconet avec Catherine II, 1767-1778. Paris: Libraire Ancienne Honoré Champion, 1921, pp. 145-146.

15. Ibidem, p. 183 and 189. Cochin went to examine the painting and decided it could not be by Rembrandt, and should not be sent to Russia, as he explained in a letter from 14 November 1772.

16. For Falconet's letters to Catherine II and the acquisitions for the St. Petersburg gallery see RÉAu, L. (ed.), Correspondance de Falconet... 
edited collection. ${ }^{17}$ Falconet never grew tired of Rembrandt. From this master he went to inspect the now lost Storm on the Sea of Galilee (figure 1), as is attested by the fact that he kept notes on what he saw, inserting some of these sightings as digressions into the ongoing edition of his Oeuvres complètes. ${ }^{18}$

What is the artistic "thinking" that Falconet unfolded when looking at Netherlandish canvases? Much of it can be summarized in his lines to Catherine II, recommending a painting by Van Dijk on account of "le plus grand art, le faire le plus vrai, le plus étonnant". ${ }^{19}$ The merits of Van Dijk's countrymen were also pinpointed in Falconet's commentaries on Pliny, published as part of his collected writings. Remarkably, Falconet, who remembered the candle-lit interiors by Robert Le Vrac de Tournières, one of the first efforts in France to emulate the Leiden Fijnschilders, thought the former less successful:

Nous avons vu des peintres faire des tableaux éclairés par un feu, par un flambeau, par une bougie, \& l'effet en étoit souvent juste: mais ces peintres n'auroient pas été assez ingénieux, pour faire un Titien, un Rubens, un Rembrandt. Demandez si M. de Tournières, qui au gré de quelques spectateurs, réussissoit dans ce genre borné, auroit approché de ces maîtres-là. Il y a certainement dans ces sortes de tableaux, du clair \& de l'obscur, \& même des reflets ; mais il ne s'ensuit pas que tous les peintres qui en sont soient initiés dans la magie du clair-obscur. ${ }^{20}$

The notion of magie, which was theorized both in the work of De Piles ${ }^{21}$ and Cochin, ${ }^{22}$ seems crucial to Falconet's understanding of the Dutch. Unfortunately, the quoted passage will not permit us to conclude what positive notion lay behind Falconet's ideas. There is more on magie and faire, again in expression of the sculptor's admiration for the Dutch, in his comparison of two Van der Helst group portraits he saw on display at the Townhouse of Amsterdam, nowadays known as the Paleis op de Dam. On a 1639 group portrait, Falconet comments, "que Van der Helst avoit alors, dans son faire, de cette magie harmonieuse", commonly seen in a Van Dijk and a Rembrandt. A later group portrait, depicting The four governors of the archers' civic guard in Amsterdam, shows a shift in style toward more descriptive representation. The greatness of Van der Helst was nevertheless not in the things shown, but in the way of showing, for the magie was not a matter of perfect likenesses in representation:

Il ne doit y avoir aucun doute que dans les tableaux d'Amsterdam la ressemblance n'ait atteint la plus parfaite exactitude. Mais ne voit-on pas des portraits où elle se trouve, \& qui sont foibles dans les autres parties? C'est donc encore d'ailleurs que de la ressemblance, que Van der Helst tire sa supériorité. $^{23}$

The Van der Helsts, which Falconet came to examine over a number of visits to the Town Hall, were to him more than excellent displays of natural precision. They were rather masterpieces in forging of a faire, a magie harmonieuse, which becomes the lens through which beholders gain a view of things accurately observed and recorded in paint. The "art of describing", to reengage Svetlana Alpers' famous dictum, was certainly present in the phraseology (la plus

17. Ibidem, pp. 109-110

18. Gelder, J.G. van, “Falconet op bezoek bij Gall van Franckenstein”, Kroniek van het Rembrandthuis, 31, 1, 1979, pp. 2-8.

19. RÉAU, L. (ed.), Correspondance de Falconet..., p. 162. The letter was signed 25 August 1771.

20. Falconet, E.-M., Euvres complètes. Paris: Dentu, 1808, p. 388.

21. On De Piles see Teyssèdre, B., Roger de Piles et les débats sur le coloris au siècle de Louis XIV. Paris: Bibliothèque des arts, 1957 ; and Lichtenstein, J., La Couleur éloquente. Paris: Gallimard, 1989.

22. Michel, C., Charles-Nicolas Cochin et l'art des Lumières. Rome: École Française de Rome, 1993, pp. $279-291$.

23. Falconet, E.-M., Euvres complètes..., vol. 1, p. 326: the Pliny commentaries were first published in 1771 and edited until Falconet's death in 1791. 
parfaite exactitude) of an admiration for the merits of the Netherlandish pictorial tradition. However, Falconet's passages testify to a more inspired pictorialism. Overtones of Falconet's magie may be found in the Italian chiaroscuro, or later in Samuel van Hoogstraten and Gerard de Lairesse's idea of economic form, houding, ${ }^{24}$ but Falconet's interlinking of that term with faire and ingenium suggests a more psychological approach, uniting the mimetic with the charismatic. This was the sense for which Piles had famously started to vindicate Rubens as new precursor of the French school. Whether from his descriptions of Rubens paintings in the collection of Cardinal de Richelieu -in the second set of the 1677 Conversations - or in his biographies, Rubens was the painter's guide, not in an art of encyclopaedic description, but in his daring showmanship. ${ }^{25}$ When he wrote of Rubens' Massacre of the Innocents, which can best be described as a full-flung spectacle of horror, Roger de Piles would not fail to notice its "merveilleux dans ses choix", and "ses oppositions \& son assemblage", underlining the painter's way with spectacle. ${ }^{26}$

There are echoes here of a notion of the image as forceful but no longer depending for this forcefulness on the object of representation proper. As René Démoris has argued, Félibien and De Piles would incrementally develop such a sense of epicurean wonder before paintings into their vocabulary of tout-ensemble, appel and surprise. Such pictorial appetite was laic, obtained by subtracting from aesthetic sensation religious concerns about divine presence in the image. ${ }^{27}$ Underneath some of this double interest in mimesis and charisma, of an interdependence between descriptive painting and magie harmonieuse, we can detect the enargeiaenergeia nexus, which played a role in early modern art theories assimilating ancient ideas about poetic speech and audience response. Enargeia is a rhetorical concept discussed in a multitude of ancient texts on rhetorics and poetology. It conveyed the sense of bringing the audience to lucidly envision a situation. ${ }^{28}$ As Valeska von Rosen has argued, the etymological roots of enargeia are luminous (as in the adjectives enargés or "clear", enárgos or "glowing up out of itself", and the noun agrós or "bright") and therefore always transcend the self-contained formal reality of a representation. In short, enargeia was an artifice which would give us a powerful illusion of having a luminous encounter. Energeia, although often amalgamated to enargeia and evidentia, stood for an economy of means: in Quintilian's understanding, it is the speech of action, where changes are constant and every word describes them effectively, without flourish. ${ }^{29}$ Enargeia-energeia prepares a method of pictorial efficacy: the cocktail of concrete mimesis, naked action and economy of means have the effect of arousing emotion and

24. See Blanc, J., Peindre et penser la peinture au XVIIe siècle. La théorie de l'art de Samuel van Hoogstraten. Bern: Peter Lang, pp. 262-266, where Blanc points out Van Hoogstraten's use of houding as a means of introducing into pictorial compositions an economy that suits the need for a sustained focus in the beholder's responses.

25. De Piles, R., Conversations sur la connoissance de la peinture. Paris: Nicolas Langlois, 1677, pp. 101-11.

26. Ibidem, pp. 111-124 for the Massacre des Innocents.

27. DÉmoris, R., "De la vérité en peinture chez Félibien et Roger de Piles: imitation, représentation, illusion", Revue d'esthétique, 31-32, 1997 [special issue Germer, S. (ed.), “La naissance de la théorie de l'art en France, 1640-1720”], pp. 36-50.

28. The impact of enargeia on theories of poetry, painting and the stage has been extensively surveyed. See PLETT, H.F., Enargeia in classical Antiquity and the early modern age: the aesthetics of evidence. Leiden: Brill, 2012, especially pp. $135-182$. For early modern exchanges between thinking poetry and thinking images see RosEN, V. vON, "Die Enargeia des Gemäldes. Zu einem vergessenen Inhalt des Ut-Pictura-poesis und seiner Relevanz für das cinquicenteske Bildkonzept”, Marburger Jahrbuch für Kunstwissenschaft, 27, 2000, pp.171-208. Caroline van Eck (EcK, C. vAN, Classical Rhetoric and the Arts in Early Modern Europe. Cambridge -New York: Cambridge University Press, 2007, pp. 7, 142-157) discusses early-modern Italian painting specifically. See also on its relevance to Netherlandish theory NATIVEL, C., "La théorie de l'enargeia dans le $D e$ pictura veterum de Franciscus Junius: sources antiques et développements modernes", Prospect, 1, 1992, pp. 73-85; and Weststeijn, T., De Zichtbare Wereld. Samuel van Hoogstratens kunsttheorie en de legitimering van de schilderkunst in de zeventiende eeuw, PhD dissertation. Universiteit van Amsterdam, 2005. pp. 153-157. On French and German eighteenth-century developments of energy (at the intersection between humanism and scientific thinking) see DeLON, M., L'Idée d'énergie au tournant des Lumières. Paris: Presses Universitaires de France, 1988, pp. 103-130.

29. On the intersection between enargeia and energeia see "Glossary of rhetorical terms", in ALDRICH, K. (ed.), Franciscus Junius, The Painting of the Ancients, according to the English translation. Los Angeles - London: Berkeley, 1991, pp. 375-380. 
deep personal investment. Orators had recourse to such "direct" and "pictional" speech as a way of swaying an audience: its function was principally to reach out and therefore to interlink the described event with the moral stances of the beholder. It was for this reason that Quintilian hailed enargeia as a technique for the courtroom: a way of making a jury judge a criminal offence by making the exact form and gravity of it apparent.

As Colette Nativel has shown, De Piles took his own tendency to amalgamate the art of painting to a vehicle of forceful "showing" from a series of passages he paraphrased and adapted from Franciscus Junius 1637 De Pictura Veterum..$^{30}$ Among them was an important distinction between the imaginations of the orator and the poet, which Junius took over for his characterization of poetic and painterly presence. The poet's imagination accumulates its fictional ideas, producing a gullible audience which savours the pleasures of the speaker's clever occurrences. Painting, on the other hand, sprang from an imagination that functioned by acts of unveiling: its beholder will be struck and feel a desire to intervene. Poems create amused complicity, while pictures confront, antagonize and stir. These "breath-taking" properties of eloquent painting, Junius's contribution to a budding French criticism of the image, entered into much of what French critics in the eighteenth century described as the cause of their admiration for Netherlandish canvases. This certainly applies to the rather pliable magie, which Falconet found in Van der Helst, Diderot in Claude-Joseph Vernet and Jean-Baptiste-Siméon Chardin, and his friend Falconet, and Claude-Henri Watelet described for Pancoucke's Encyclopédie méthodique as a "science surprenante [qui] n'est en effet aujourd'hui que le pouvoir des âmes sur les âmes." ${ }^{31}$

\section{The Flemish Violent Body}

The major factor for a Netherlandish-French exchange seems to reside in the link between sculpture and imagery for which Netherlandish masters were becoming noted, but which need not have consisted of sculpture. This image criticism from which sculptors were to benefit would then have been developed through the countless paintings and prints of Flemish and Dutch imprimatur passing before the eyes of sculptors and their clients. Michel de Marolles, a courtier of Louis XIV and owner of a highly respected engravings collection, may have played an important role in getting French artists to encounter and master a Flemish language of forceful images. This happened well before the booming trade in Netherlandish paintings: Marolles was the author, in 1655, of a learned edition of mythological tales, the Temple des Muses. In this book, he published an astounding series of engravings after drawings by a disciple of Rubens, Abraham van Diepenbeeck. ${ }^{32}$ As can be seen in his plates illustrating the story of Isis and Argus (figure 2) and his Fall of Icarus, part of the thrill of the images comes from the way they strongly undermine anything like a "group" in Franco-Italian history painting. Diepenbeeck's work insistently isolates figures, turns them on their head, shows them in disarray. In the case of the beheaded Argus, the engraver would allow for a spectacle of dismemberment matched only by what con-

30. See Nativel, C., “Ut pictura poesis: Junius et Roger de Piles”, Dix-septième siècle, 245, October, 2009, pp. 593-605. 31. Watelet, C.-H., "Magie”, in Encyclopédie méthodique, Beaux-Arts. Paris: Charles-Joseph Panckoucke, 1788-1791, vol.1, pp. $485-87$ (p. 487).

32. On this Macallister Johnson, W., “From Favereau's Tableaux des vertus et des vices to Marolles' Temple des muses. A conflict between the Franco-Flemish schools in the second quarter of the seventeenth century", Gazette des beaux arts, 71, 1968, pp. 171-190 ; and ChATELAIN, M.-C., Ovide savant, Ovide galant: Ovide en France dans la seconde moitié du XVII siècle. Paris: Champion, 2008, pp. 239-261. 


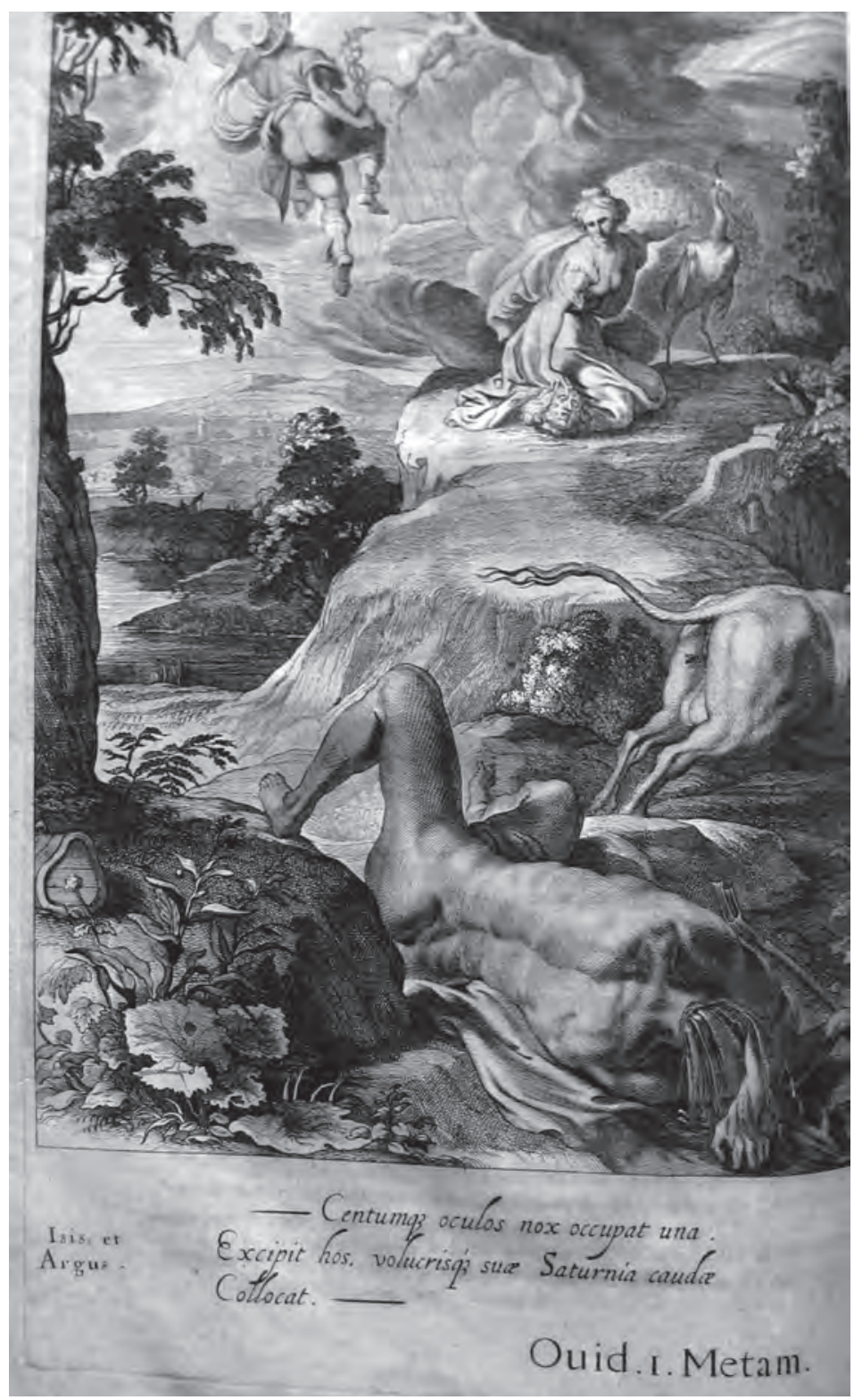

2. Cornelis Bloemaert and Theodor Matham (engravers) Abraham van Diepenbeeck (inventor) Isis and Argus, engraving, in Michel de Marolles, Temple des Muses, Paris: Antoine de Sommaville, 1655, no. XXIX.

temporaries could have seen at the gallows: the muscular, still actively gesturing torso, topped by a sliced neck, has metamorphosed into a shimmering fountain of blood.

The Flemish violent body harmonized well with the confrontational approach associated, after Junius, with pictorial imagination, and with the criminal associations of the "illuminated" event in enargeia. This becomes conspicuous in Diepenbeeck's most dramatic engravings in his mastery of compositional devices that seem calculated to put the beholder in a state of discomfort and schadenfreude. What to make of the prominence of a central pathetic body, disconnected from other figures and dominating not just overall compositional directionality, but also facing out and foreshortened as if breaking into the beholder's space? This foregrounding of gore is sustained by the sense of momentary snapshot movement, the uncanny manipulation of light and dark, and an insistent appeal on subsidiary fact, such as in the cow running off the frame in Isis and Argus. In Isis, the clouds crown the flashing movement of the victim, as happens with the solar rays, piercing the despaired Icarus. The landscape setting, which replaces "conversing" figures, functions effectively as a vessel for metaphorical readings. In Diepenbeeck's rendition 
3. Cornelis Bloemaert and Theodor Matham (engravers) Abraham van Diepenbeeck (inventor) Meleager, engraving, in Michel de Marolles, Temple des Muses, Paris: Antoine de Sommaville, 1655, no. XXI.

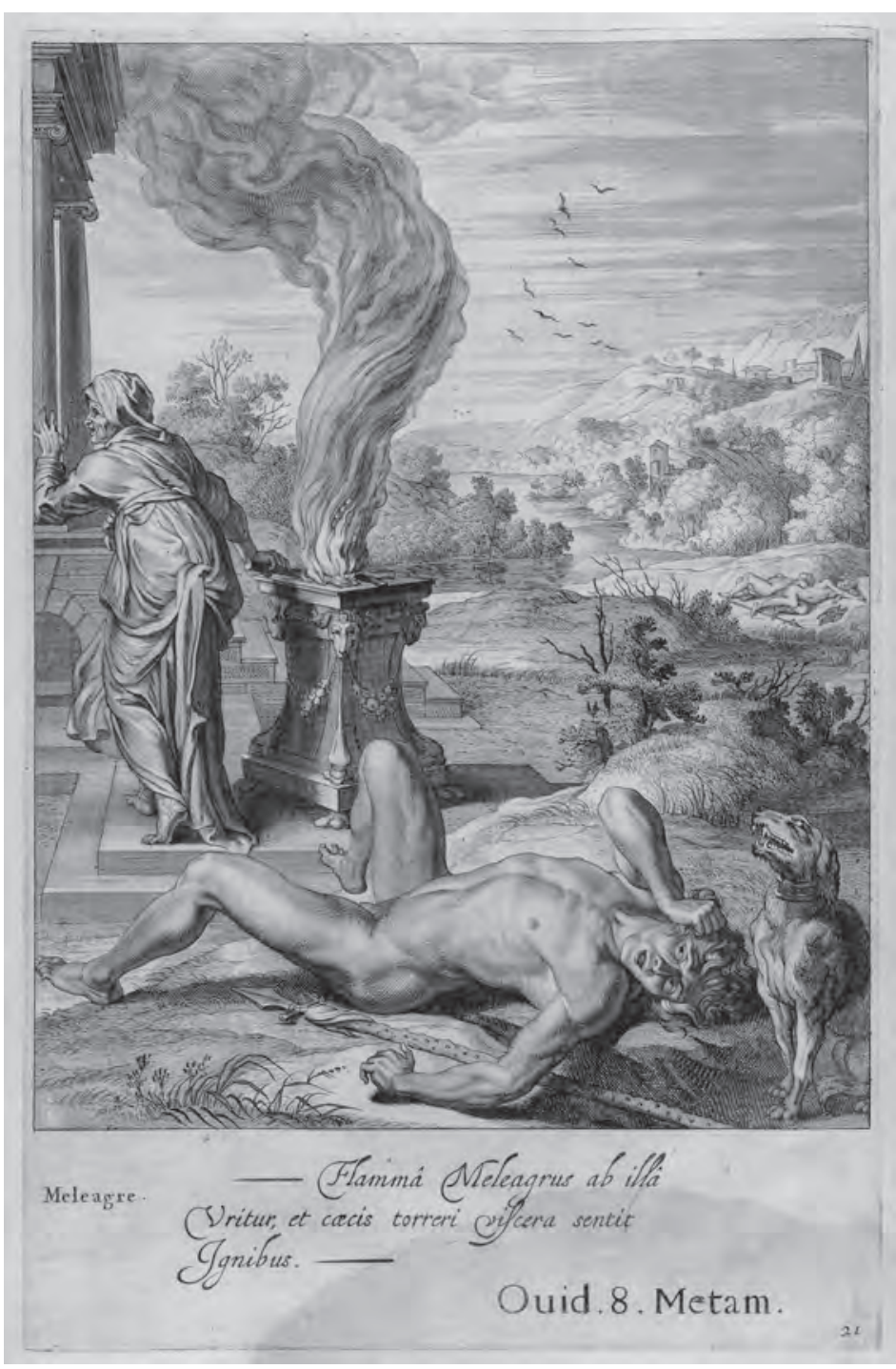

of the story of Meleager (figure 3), one can see the fire as a metaphor for the body's anguished "melting" on the inside, while the pillar of smoke, a layered, elegant whirl in clair-obscur, echoes Meleager's contorting body. The strange choreography of these added semi-images is not just emblematic enhancement, but also analogical play. They make for a sense of echo and outward repetition of gestures and afflictions of the lonely victim, becoming allusions to the look and feel of bodily agitation and sudden death. ${ }^{33}$

In Flemish painting, violent body images were reserved for iconographical allusions to the fall of man, as in Michiel Cocxie's Cain and Abel or the famous Rubensian canvases on themes of the Prometheus Bound and the Fall of Phaeton and Hippolytus. To elaborate a possible trajectory for violent scenes of this kind in French sculpture, I will briefly discuss three examples that in my view offer evidence for an adopted aesthetics of compositional condensation, action and effective mimesis. First is François Lespingola's Prometheus Being Rescued by Hercules (I refer to the Rijksmuseum version from about 1670), which has usually been linked to Florentine

33. See for a similar analysis of visual metaphor in Netherlandish art BANN, S., The true vine: on visual representation and the western tradition. Cambridge: Cambridge University Press, 1989, in particular chapter 2, "Are they thinking of the grape?". 


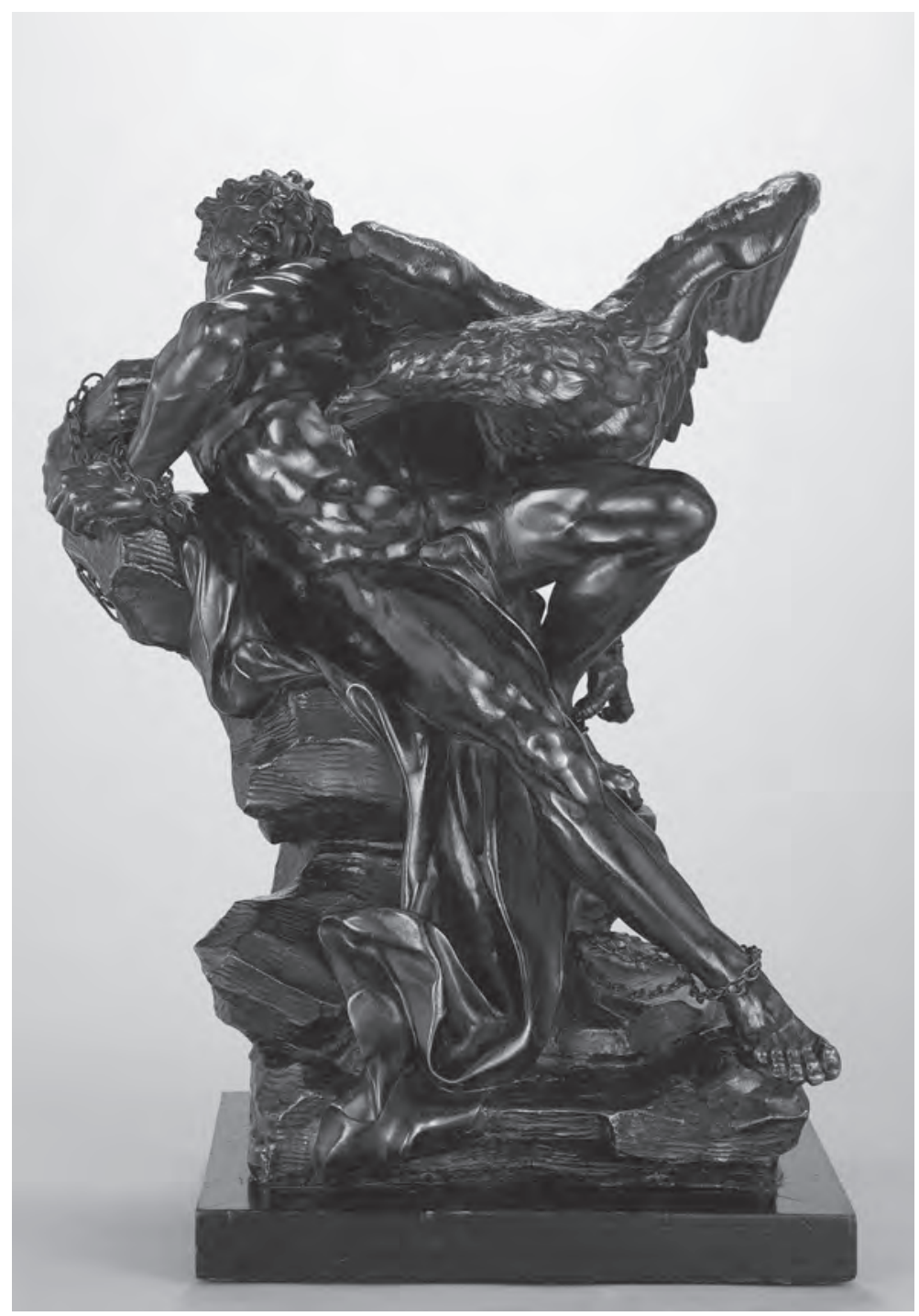

4. Philippe

Bertrand

Prometheus

Bound, 1703,

bronze,

$49,2 \times 42 \mathrm{~cm}$.

Royal Collection

Trust, HM Queen

Elizabeth II.

bronze sculpture developments, ${ }^{34}$ but whose use of an inverted and swivelling victim speaks to Flemish antecedents. So does the snapshot view of the falling movement of Prometheus and sweeping sideward turn, all far removed from Italian "conversational" compositions typified in France by Corneille van Clève's gentle groups of lovers from 1704.

Less directly indebted to Rubens, but Flemish nevertheless for the prominence of a strongly dramatized, disassembling body and almost traumatic sense of immediacy, is the beautiful bronze Prometheus Bound by the bronze-casting specialist Philippe Bertrand (figure 4), exhibited in the Salon of $1704 .{ }^{35}$ The bronze Prometheus seems to encapsulate an entire aesthetics of enargeia, looking in particular to models from the school of Rubens where the body is given strong visceral movement, and where accessories such as the eagle and rocky base, tightly in-

34. See on Lespingola's bronze model, executed in two variants, SoucHaL, F., French sculptors of the seventeenth and eighteenth Centuries: the reign of Louis XIV, 3 vols., Oxford-London: Cassier, 1977-1987, vol. 2, p. 420; SCHOLTEN, F., "Keuze uit de aanwinsten", Bulletin van het Rijksmuseum, 56, 4, 2008, p. 480; and Bresc BAUTIER, G.; ScherF, G., Bronzes français..., pp. 294-297.

35. On Philippe Bertrand and the Prometheus Bound see Souchal, F., French sculptors..., vol.1, p. 52; and BRESC BAUTIER, G.; SCHERF, G., Bronzes français..., pp. 388-393. 
5. Guillaume

Coustou I

Hercules

on the Pyre, 1704,

marble,

$74 \times 63 \mathrm{~cm}$.

Musée du

Louvre, Paris.

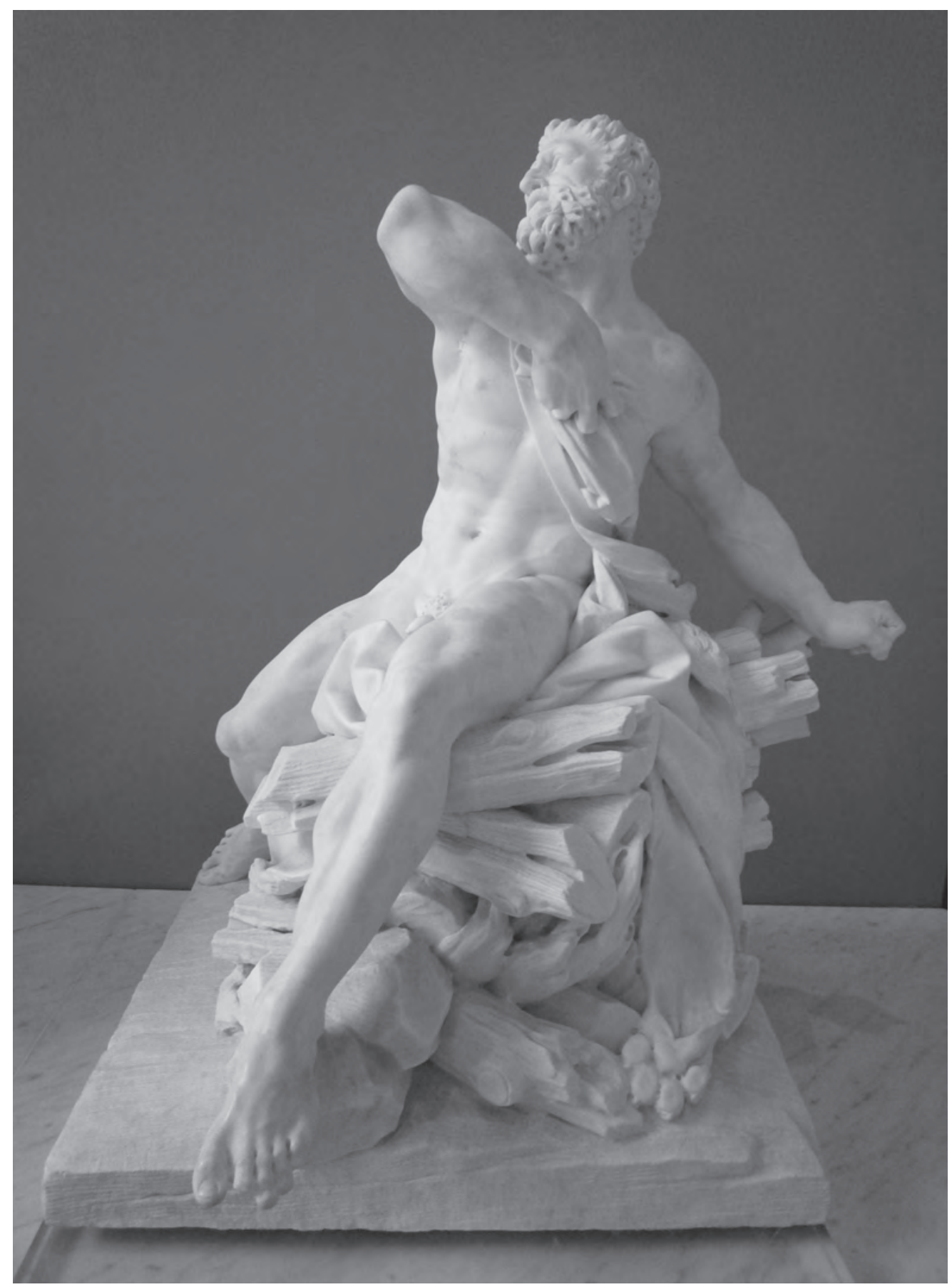

terconnected with one another, seem compressed, compositionally, with the action of the body, almost as if they were a natural metaphor of the body's afflicted state. This effect appears again in Guillaume Coustou's morceau de réception, the Hercules on the Pyre, which had some pictorial ancestors (figure 5). Both Bertrand and Coustou seem to have put the wood, rock and eagle to good use as a form of "mirroring" that captures a graceful surge in the body of the isolated hero: Coustou's Hercules has the look of a branching tree of smoke or flames flaring up from the pyre. The Flemishness of Bertrand and Coustou is not simply a function of violent subjectmatter, but of the two sculptors' stress on raw drama solved compositionally, by insisting on vivid and arresting presentation. 


\section{“C’EST LUI QUe EÛT ÉVOQUÉ LES OMBRES”}

In a passage from Falconet's essay Sur deux Peintures de Polygnote, the French sculptor and promoter of magie imagined Rubens painting the theme of Ulysses having a vision of the underworld, a theme known from Homer. Rubens becomes a Miltonian renegade-a visionary of things inside the dark:

Le beau sujet pour une tête poétique ! Quels effets ! quels ressorts ! quelle magie de couleurs, de lumière \& d'ombre ! quelles machines un Rubens eût fait jouer ! C'est lui que eût évoqué les ombres \& tous leurs présages ; il nous eût mené aux enfers. ${ }^{36}$

It is well known how lastingly Rubens contributed to making painters understand the delight of colour. Art history might yet discover how the Netherlandish tradition could have become useful to sculptors by making more of the isolation of their marble and bronze figures, and by compressing the body with animals, plants and rocks to explore the allusive potential of the composed body of sculpture. The availability of an audience psychology, detected by Falconet and others in the Netherlandish penchant for magie, and made available in the form of a violent body, hides an insight useful to anyone willing to puzzle over how French sculpture evolved from Girardon's detached Apollo's Bath to the “breath-taking” Marly Horse Tamers, those works François Souchal thought anticipated romanticism in the 1740 .

36. FalConet, E.-M., Euvres complètes..., vol. 2, p. 127. The Polygnote essay finds its origins in Falconet's correspondence with Diderot in the 1760 s. 